\title{
Sustainable Model Study: Collection and Disposal of Waste Medications with Micropollutant Properties in the Ecosystem within the Scope of Zero Waste
}

\author{
Zeynep CEYLAN ${ }^{1 *}$ D, Şahin KORKMAZ ${ }^{2}$ \\ ${ }^{1}$ Atatürk University, Faculty of Engineering, Environmental Engineering, Erzurum, TURKEY
}

Geliş / Received: 01/07/2019, Kabul / Accepted: 17/07/2019

\begin{abstract}
Waste medications forming a very broad portion of micropollutants (with high EDC effects) are known to be very dangerous for the ecosystem and are not sufficiently treated in conventional treatment facilities leading to discharge into surface and underground water, threatening the ecosystem and human health as they pass into drinking water and soil. The metabolite products formed during cycles of these micropollutants (MP) in the ecosystem may be toxic and dangerous to the same degree or even more. Within the framework of zero-waste policies, this study was completed with the aim of finding a more permanent and sustainable solution to this important problem based on the most effective and applicable method of controlling these pollutants at the source. Ataturk University campus located in Erzurum was chosen as a pilot application area and speciallydesigned Waste Medication Collection Containers were placed at five different points determined by observing different factors.

Waste medications collected from the containers were emptied in seasonal periods (once in 3 months) and sent to IZAYDAS for incineration through a ministry-licensed and accredited hazardous waste intermediate storage company.

A total of $190.75 \mathrm{~kg}$ was collected during the first 3-month period (summer season), with $261.40 \mathrm{~kg}$ collected during the second 3-month period (autumn season), $310.70 \mathrm{~kg}$ collected during the third 3-month period (winter season) and $260.80 \mathrm{~kg}$ collected in the fourth 3-month period (spring season). A total of $1023.65 \mathrm{~kg}$ of waste medication was collected and destroyed during the one-year period. Data collected were analyzed with the SPSS statistical program (one-way ANOVA) according to seasonal changes.

In addition, social information and awareness studies (details presented in article) continue at a rapid rate.

Keywords: Waste Medication, Micropollutant, Waste Medication Collection Containers, Hazardous Waste, Social Awareness.
\end{abstract}

\section{Ekosistemde Mikrokirletici Özellik Gösteren Atık İlaçların Sıfır Atık Kapsamında Toplanıp Bertarafı :}

$\ddot{O} \mathbf{z}$ Sürdürülebilir Model Bir Çalışma

Mikrokirleticilerin (EDCs etkisi yüksek) oldukça geniş bir bölümünü oluşturan atık ilaçlar; ekosistem için çok tehlikeli olup bilindiği gibi konvansiyonel arıtma tesislerinde yeterince arıtılamadığı için tekrar yüzeyel ve yer altı sularına deşarj edilerek içme sularına ve toprağa geçmek suretiyle ekosistem ve insan sağlığını tehdit etmektedir. Bu mikrokirtecilerin (mk) ekosistem içindeki döngüleri esnasında oluşan metabolit ürünleri de aynı derecede hatta bazen daha toksik ve tehlikeli olabilmektedir. Sıfır atık politikası çerçevesinde en etkin ve uygulanabilir metodun kirleticilerin kaynakta kontrol edilmesi gerçeğinden hareketle bu önemli soruna daha kalıcı ve sürdürülebilir bir çözüm bulma adına yaptığımız çalışmada, Erzurum merkezde bulunan Atatürk Üniversitesi Kampüsü pilot uygulama alanı seçilmek suretiyle değişik faktörler gözetilerek belirlenmiş beş farklı noktaya özel tasarlanmış Atık İlaç Toplama Konteynırları yerleştirilmiştir.

Toplanan atık ilaçlar mevsimsel peryotlarda ( 3 ayda bir) boşaltılarak, bakanlıktan lisanslı ve akredite bir tehlikeli atık ara depolama firması üzerinden IZZAYDAŞ’a yakmaya gönderilmiştir.

Birinci üç aylık süreçte (Yaz mevsimi) toplam 190,75 kg, ikinci üç aylık süreçte (Sonbahar mevsimi) toplam $261,40 \mathrm{~kg}$, üçüncü üç aylık süreçte (Kış mevsimi) toplam 310,70 kg ve dördüncü üç aylık süreçte ise (İlkbahar mevsimi) toplam $260,80 \mathrm{~kg}$ olmak üzere bir y1llık peryotta toplam $1023,65 \mathrm{~kg}$ atık ilaç toplanarak imhas1 sağlanmıştır. Toplanan veriler mevsimsel değişimlere göre istatistiki SPSS programı ile (One Way ANOVA) detaylı olarak analiz edilmiştir.

Tüm bunların yanı sıra sosyal bilinçlendirme ve farkındalık çalışmaları da (makalede detayları sunulmuş) son hizla devam etmektedir.

Anahtar Kelimeler: Atık İlaçlar, Mikrokirletici, Atık İlaç Toplama Konteynırı, Tehlikeli Atık, Sosyal Bilinçlendirme. 


\section{Introduction}

Control of one of today's most important problems of waste medication, without harming the environment or human health, is a very important topic. Medication may become waste in homes, pharmacies-depots and health organizations due to passing best-by dates; lack of use due to healing, stopping medication use, or overprescription; disrupted or damaged packaging due to storage in inappropriate conditions (temperature/light/humidity); or contamination due to accidental spillage. Waste medication is accepted as a class of hazardous waste with toxic and refractory (resistant to biodegradation) features due to the organic origin of the effective ingredients. Waste medications consistently accumulate mainly in health organizations, depots and homes periodically. Research has shown that $80 \%$ of waste medication accumulating in homes is disposed of by being thrown in the garbage or flushed down the toilet, while only $20 \%$ is surrendered to health organizations. The fate of medications given to health organizations is a controversial topic.

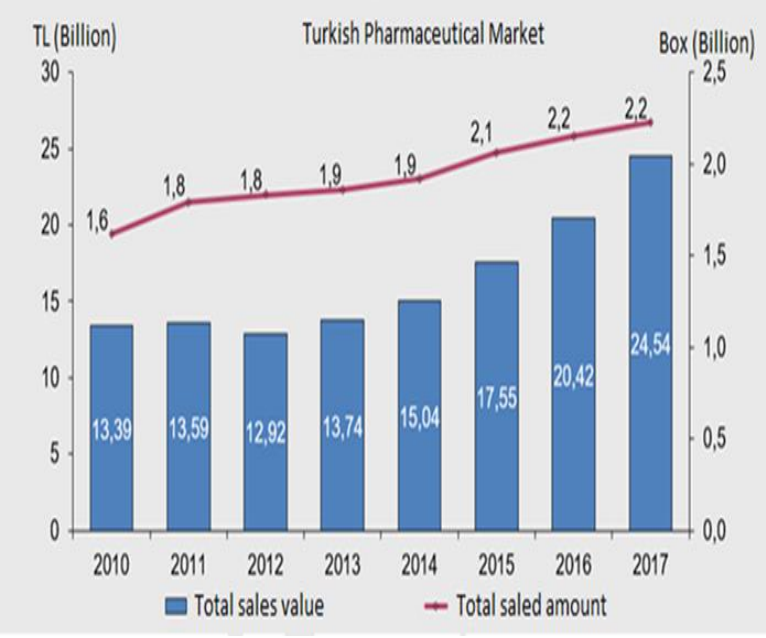

Figure 1. Turkish pharmaceutical market (IEIS, 2019).
Waste medication being thrown in the garbage or flushed down the toilet makes our drinking water unusable. Medications thrown in the garbage are a potential danger to children and animals living on the street, and fluid seeping from garbage may contaminate soil and groundwater. Medications flushed down toilets or sinks reach treatment plants which increases the dangerous organic micropollutant load in urban sewage systems. As waste medication is considered a micropollutant, it is not sufficiently treated by conventional treatment plants and threatens the ecosystem and human health by entering water again, the soil and even the air (Segura et al., 2011; Ribeiro et al., 2015; Barbosa et al., 2016; Tousova et al., 2017). When waste medications enter the air, water or soil they may have ecotoxic effects on cultivated plants, drinking water, aqueous organisms and fish. Apart from this, EDCs may cause serious harm to the immune system, reproductive system and hormonal system in humans leading to problems that cannot be ignored (World Health Organization 2012; Muter et al., 2017; Park et al., 2017; Sousa et al., 2018).

Waste medications, causing many problems in environmental ecosystems and also causing negative pressure on environmental and human health, are within the micropollutant class. Micropollutants may be due to industrial or anthropogenic sources, and even at very low concentrations in water and wastewater they have chronic toxic (mutagenic, teratogenic, carcinogenic) and/or endocrine disruptive chemical (EDC) effects (large effects from small amounts). With very different features in terms of 
physicochemical properties, these are "problematic" chemicals in terms of treatment. In spite of low quantity amounts, these micropollutants are refractory in water and soil, are persistent and mostly of organic origin and mix with wastewater in treatment facilities and may discharge and mix with soil, groundwater, mud, sediments and even our drinking water (Ceylan and Mustafaoğlu, 2018).

Micropollutants may be investigated under two headings as organic and inorganic. In the organic micropollutant class there are pesticides, polyaromatic hydrocarbons (PAH), persistent organics (PO), hormones (natural and synthetic, medications (antidepressants, antibiotics, chemotherapy medications, etc.), personal care products (shampoo, creams, etc.), drugs and narcotics, microplastics, and surfactants. Organic nanochemicals include a broad range of products. In the inorganic micropollutant class, there are nanomaterials, metals-semimetals and radioactive elements (lead, cadmium, mercury, arsenic, antimony, radon, uranium, etc.).

With difficult biologic and chemical degradability, micropollutants appear to cause great harm to the ecosystem by mixing with water or wastewater. Due to bioaccumulation in living organisms (lipophilic), most micropollutants are toxic and carcinogenic. Forming a large portion of these micropollutants, nearly $70 \%$ of pharmaceuticals and personal care products are thrown into domestic waste water, with $20 \%$ coming from agriculture and animal husbandry and the remaining portion from hospitals and health organizations (Margot et al., 2015; Das et al., 2017; Ceylan and Mustafaoğlu, 2018).

When investigating the fate of micropollutants after they enter the ecosystem, the interacting transport routes in air-water-soil/sediment are important. The transport and transformation processes from air to water, water to air-soil and sediment (Table 1) may be observed in flora and fauna linked to the physicochemical features of micropollutants (molecular structure and mass, melting-boiling point, condensation pressure, volatility, water solubility/hydrophilicity, fat solubility/lipophilicity, distribution coefficients between water/sedimentwater/soil-water/natural fats, $\log \mathrm{Kow}, \mathrm{KH}$, Koc, KD values, etc.) (Padhye and Tezel, 2013). 
Table 1. Processes involving micropollutants in environmental ecosystems (Mill, 1980)

\begin{tabular}{|c|c|c|}
\hline ECOSYSTEM & TRANSPORT & TRANSFORMATION \\
\hline Air & $\begin{array}{l}\text { Meteorological } \\
\text { transport } \\
\text { Diffusion/dispersion } \\
\text { Precipitation/rain }\end{array}$ & $\begin{array}{l}\text { Photolysis } \\
\text { Oxidation }\end{array}$ \\
\hline Water & $\begin{array}{l}\text { Retention } \\
\text { Evaporation } \\
\text { Biointake }\end{array}$ & $\begin{array}{l}\text { Photolysis } \\
\text { Hydrolysis } \\
\text { Oxidation } \\
\text { Metabolism/biological } \\
\text { degradation }\end{array}$ \\
\hline Soil/Sediment & $\begin{array}{l}\text { Retention and } \\
\text { sediment flow } \\
\text { Evaporation } \\
\text { Enrichment } \\
\text { Biointake }\end{array}$ & $\begin{array}{l}\text { Photolysis } \\
\text { Hydrolysis } \\
\text { Oxidation } \\
\text { Reduction } \\
\text { Metabolism/biological } \\
\text { degradation }\end{array}$ \\
\hline
\end{tabular}

Research into the presence of micropollutants in the three basic elements of the environment of air, water, and soil/sediment and their fate continue intensely. Among micropollutants, studies about the presence and fate of medications, especially, personal care products and pesticides within soil and aquatic environments have reached notable dimensions. There are countless studies revealing the presence and fate of these in surface water led by sewer water-urban waste water treatment facilities, in groundwater and drinking water and also in soil (Luo et al., 2014).
Micropollutants found in aqueous environments have become an environmental and health problem with worrying dimensions for the ecosystem and organisms living in the ecosystem (Kolpin, et al., 2002; Emmanuel et al., 2004; Hernando et al., 2006; Verlicchi et al., 2010; Deblonde et al., 2011; Luo et al., 2014). Pollutants called micropollutants increasing with rapid rates in recent years display rapid spread in the environment with both natural and anthropogenic activities (Cordy et al., 2004; Vieno et al., 2007; Arp, 2012; Loos et al., 2013; Phillips, et al., 2015; Yang and Zhang 2016). 
Micropollutants are found at microlevels in waste water from health organizations and hospitals, in addition to domestic waste water. They are accepted by the EPA as new xenobiotic chemicals threatening human and environmental health at serious dimensions with all aspects currently unknown (Schwarzenbach et al., 2006; Leminh et al., 2010; Yaşar et al., 2013; Burke et al., 2014; Gulde et al., 2016; Nas et al., 2017).

In this study, as emphasized above, micropollutants are one of the most common types occurring the ecosystem, with countless studies performed or being performed about medication which has become waste. This study aims to share the statistical results of our pilot application of a practical solution that can easily be applied in all cities in Turkey in general, whereby these medications are collected and accumulated in sustainable fashion before they can be dumped into the ecosystem.

In fact, within the framework of the zerowaste policy rapidly being adopted in our country, our study was completed as part of the "take precautions before pollution, recycle if possible" principle with the possibility for continuation and development.

In the name of solving this current problem, some pharmacies or family health centers have set up waste medication containers in an attempt to collect medications. However, medications collected in the warm indoor temperatures in buildings in plastic or cardboard containers become a problem due to being left in inappropriate conditions and not being sent to the necessary facilities at defined periods. Most of the time collected waste medication is placed in several layers of plastic bags and left in domestic waste containers.

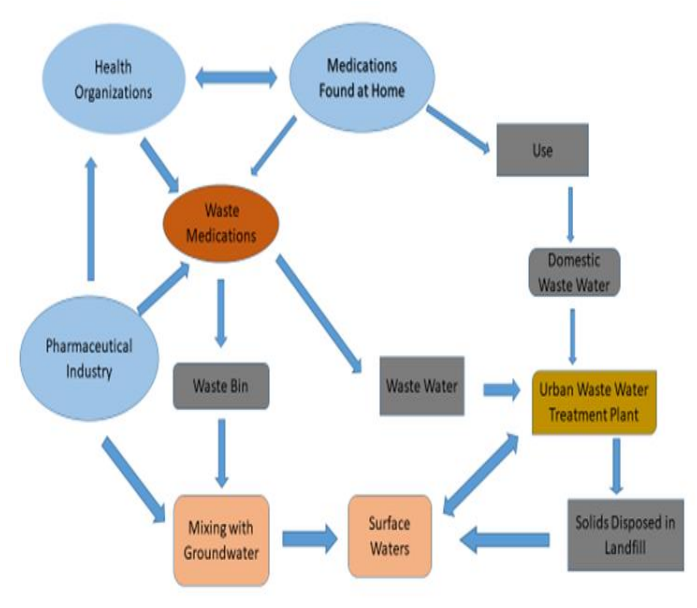

Figure 2. Cycle of pharmaceuticals to waste medications.

As there are no circumstances allowing for the reuse of waste medication (medication left in uncertain conditions), it is necessary to collect the medication, store it and send it to disposal facilities. The necessary conditions for collection of waste medication are stated in the 6th item in the Control of Hazardous Waste directive (Official Gazette number 25755, Date 14.03.2005) (CSB, 2019; Resmigazete, 2019a).

The steps before destruction after collecting hazardous waste are that intermediate storage should be completed safely and must be performed within the framework of criteria stated in the hazardous waste storage facility directives (Resmigazete, 2019b).

In the name of solving this current problem, some pharmacies or family health centers have set up waste medication containers in an attempt to collect medications. However, medications collected in the warm indoor temperatures in buildings in plastic or 
cardboard containers become a problem due to being left in inappropriate conditions and not being sent to necessary places in certain periods. Additionally, pharmacies undertaking this task must code each waste medication one-by-one and enter them into the Waste Medication Collection System (WMCS) program; after registering the medications the total sales price apart from VAT must be imaged and listed. This is not practical in application and is a heavy responsibility for pharmacies (BEK, 2019).

To avoid all these problems, collecting waste medication alone separate from other types of waste in special risk-free containers and transporting them to incineration facilities is a situation that should be carefully presented.

medication collection containers were placed at five points determined within the campus. These points were chosen due to ease of access and being the most appropriate in the campus. Points chosen for container placement were under 24-hour surveillance by security cameras operated by Atatürk University security.

Additionally, as the air temperature in Erzurum is mainly cold, the continuous cold especially at depth in the soil provided an important advantage for our study.

\section{Material and Method}

\subsection{Study Area}

Within the scope of this study, Atatürk University located in central Erzurum was chosen as pilot application area. Waste medication collection containers were placed at five points determined within the campus. These points were chosen due to ease of access and being the most appropriate in the campus. Points chosen for container placement were under 24-hour surveillance by security cameras operated by Atatürk University security. Additionally, as the air temperature in Erzurum is mainly cold, the continuous cold especially at depth in the soil provided an important advantage for our study.

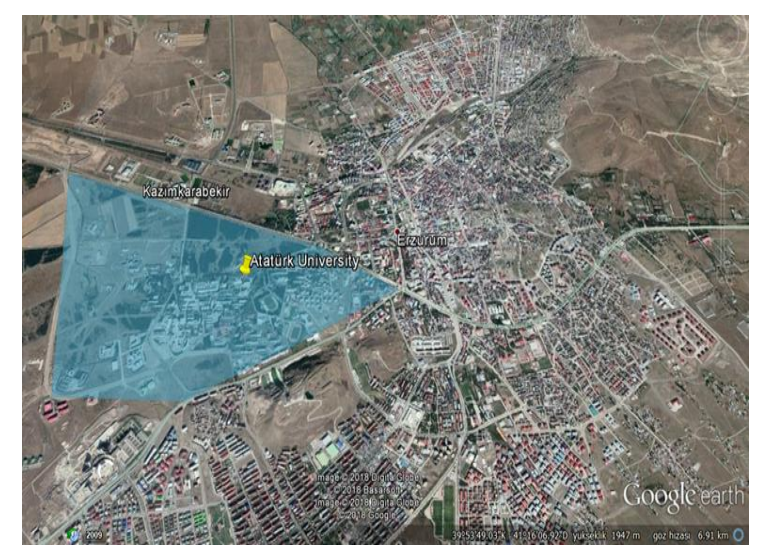

Figure 3. Geographical location of the study area.

The five main points where the waste medication collection containers were located within Atatürk University campus are as follows:

1. Credit Dormitories Institution (Kyk) Female Dormitory Entrance (Kyk Female Dorms)

2. In Front Of The Mosque In The Residences (Residences)

3. At The University Bank And Shopping Center (University Entrance)

4. Between The Dentistry And Research Hospital (Dentistry)

5. Clinic Exit From The Research Hospital (Research Hospital) 
The locations of the 5 main points where containers were placed in Atatürk University campus linked to Erzurum/Yakutiye county are shown in Figure 4.

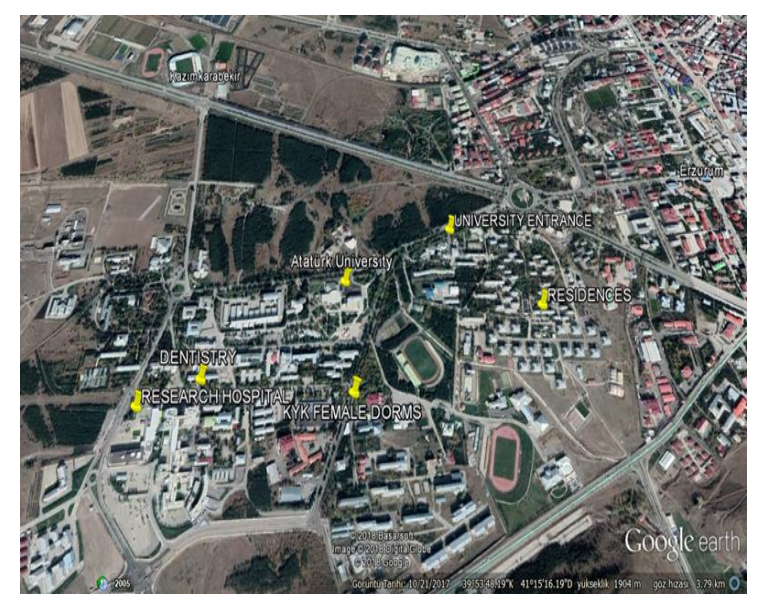

Figure 4. Location of waste medication containers.

\subsection{Study Method}

Five waste medication collection containers were located within Atatürk University campus. Waste medications were collected at the end of the $1^{\text {st }}$ period from 1 June 2018-31 August 2018, at the end of the $2^{\text {nd }}$ period from 1 September 2018-30 November 2018, at the end of the $3^{r d}$ period from 1 December 2018 - 28 February 2019 and at the end of the $4^{\text {th }}$ period from 1 March 2019-31 May 2019.
Thus, in order to complete all seasonal (summer-autumn-winter-spring) statistics, the year was separated into four periods and containers were emptied four times per year.

In order to effectively collect waste medications, specially-designed containers were used. Figure 5 shows the above and below ground sections of the waste medication collection containers. Figure 6 shows the polymeric sack placed within the waste medication collection container. The container body is a single piece with no joins and most of it is buried within the soil. It is definitely waterproof and leakproof. A 1.6-meter section of the container is buried in the ground. Thus, the placement does not take up much space and has a structure that is not affected by temperature, light and humidity. Both the main lid and filling lid can be locked. There is no way to access the inside and retrieve any medications. Additionally, as shown in Figure 5b, the interior of the buried main body is made of a mobile polyethylene-polypropylene mixture with ergonomic design with medications dropped directly into a mobile sack system. 


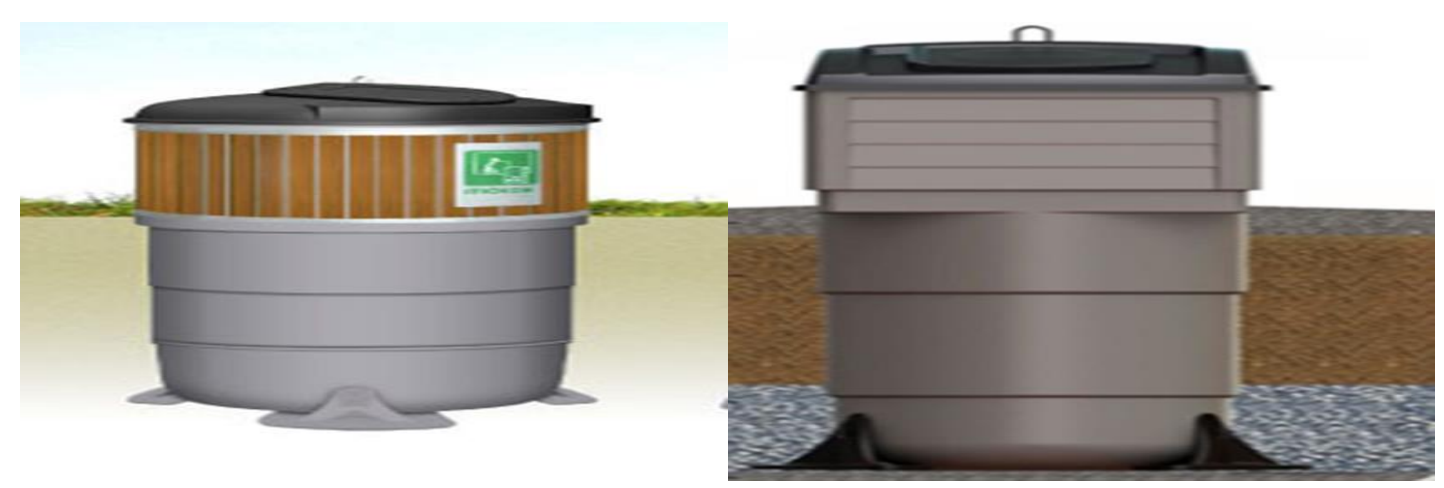

Figure 5. (a) Structure of waste container,

(b) Location of waste medication container in the ground.

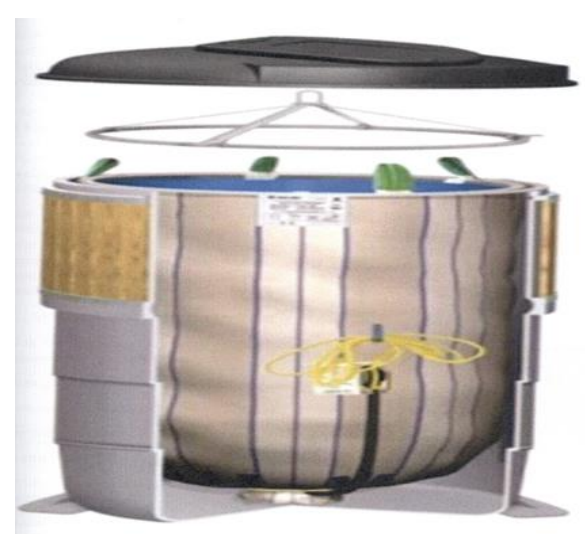

Figure 6. Cross-section of waste container.

Each waste medication container has 800 liter volume, with capacity to hold almost $80 \pm 10 \mathrm{~kg}$ waste medication when full based on measurements and calculations. With 5 containers placed within the university campus boundaries, in each period (3 months) nearly $400 \mathrm{~kg}$ can be collected with $1200 \mathrm{~kg}$ (1.2 ton) collected each year.

After the design stage for the containers, the setup stage buried the waste medication collection containers 1.6 meters under the ground. Figure 7 shows images from the setup stage. 


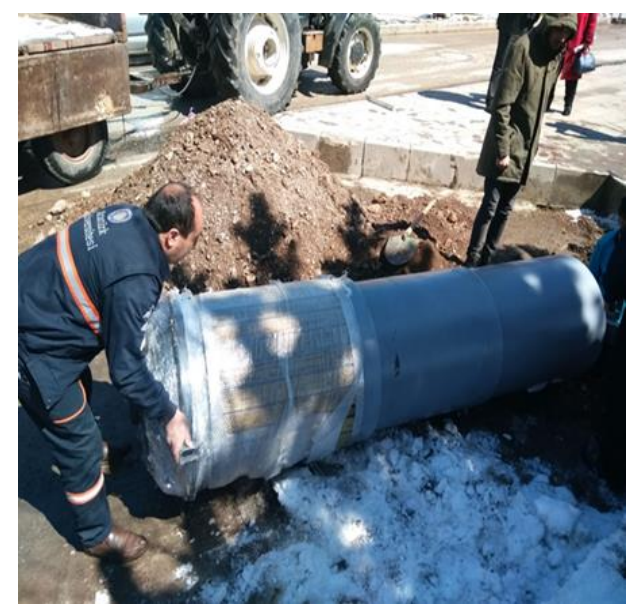

Figure 7. (a) Setting up waste medication containers,

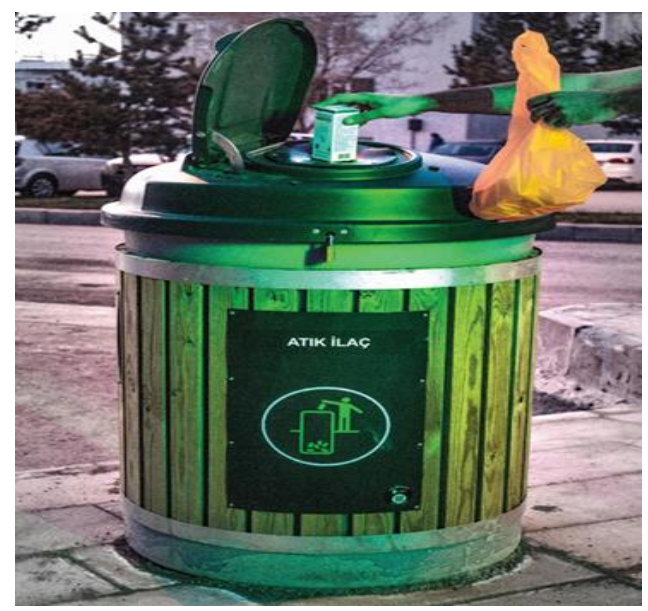

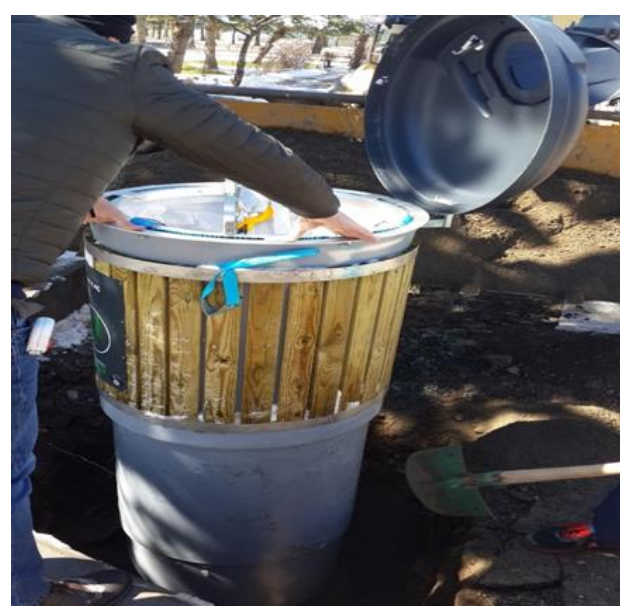

(b) Placement of waste medication containers in the ground.

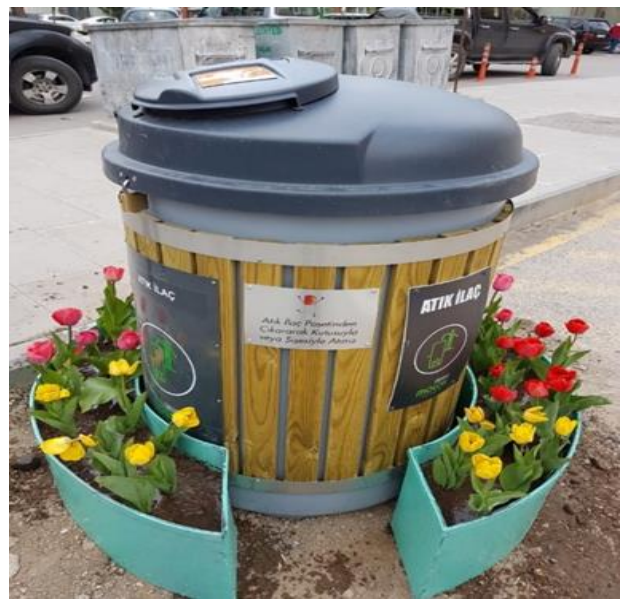

Figure 8. General appearance of waste medication containers.
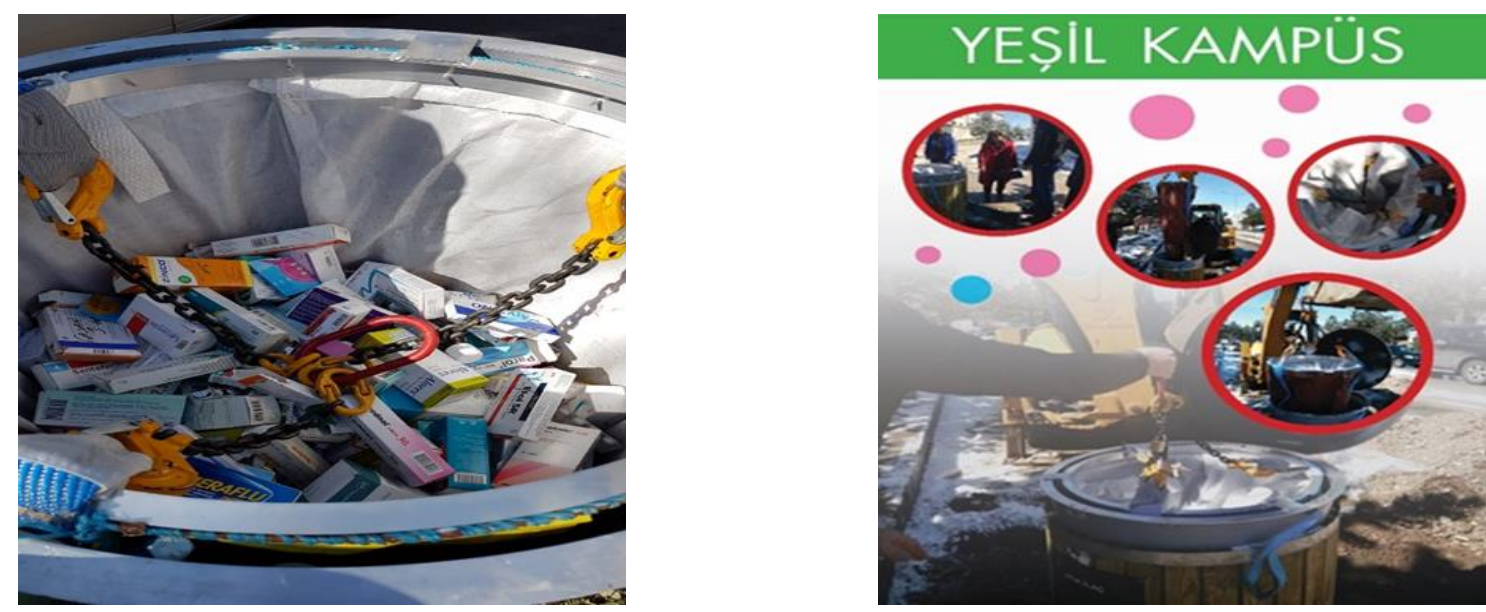

Figure 9. Appearance of container filled with waste medication (Residence point).

After waste medication is collected in this container, they can be removed with the special sack system shown in Figure 10. This sack system is one hundred percent 
leak proof and can be removed from within the container with the aid of handles at the top. The sack can be emptied into previously prepared boxes without touching the medications by pulling on a cord at the side (Figure 10b). After sensitive weight measurements, boxes are labelled with waste medication codes (radioactive medications are not included in this scope) as shown in Figure 11a and sent to an

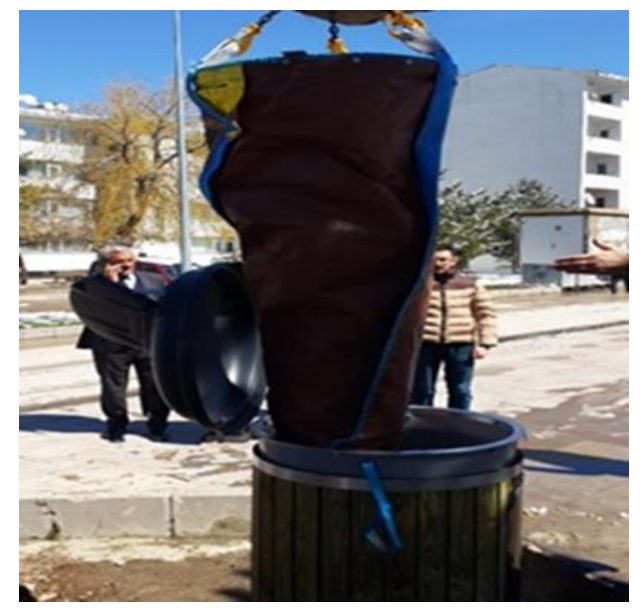

Figure 10. (a) Special sack system is inserted

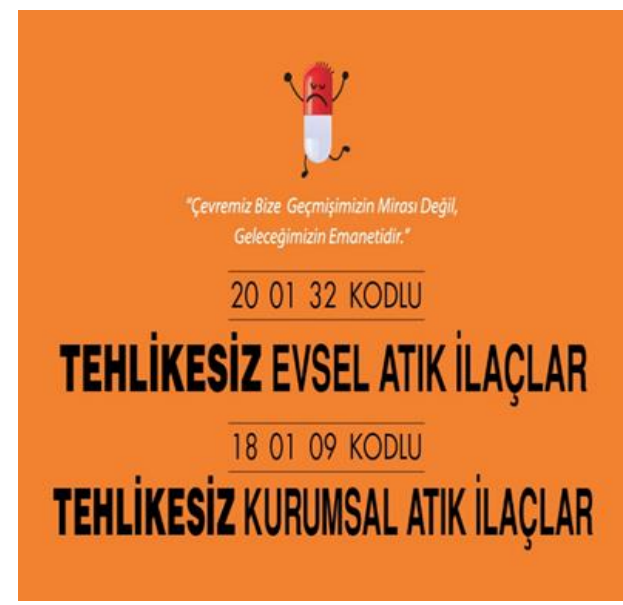

Figure 11. (a) Labels for coding waste medication, intermediate storage facility by cargo (Figure 11b). The waste medication sent to the intermediate storage facility, in agreement with Atatürk University Rectorate, is accumulated until a certain tonnage is reached and then sent directly to the IZMIT Waste and Residue Treatment Incineration and Utilization Corporation (IZAYDAS) incinerator plant.

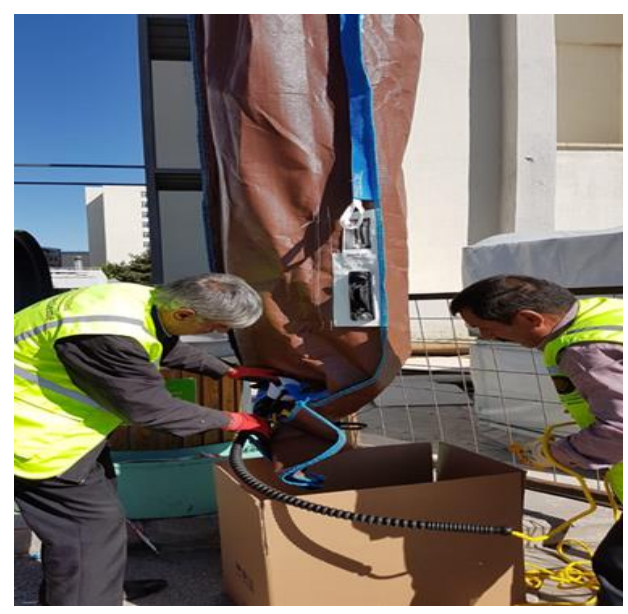

(b) Emptying waste medication inside the container

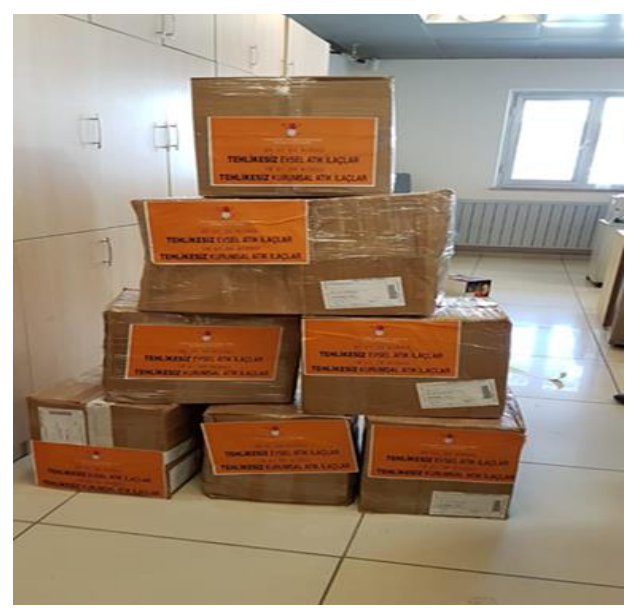

(b) Boxes with waste medication coding labels attached. 


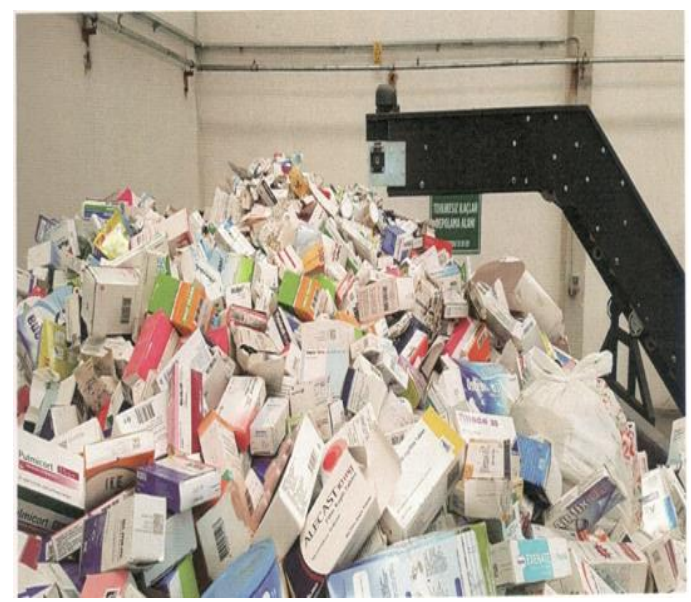

Figure 12. Waste medication stored in the intermediate storage facility

The hazardous waste storage and incinerator facility at IZAYDAS where the collected waste medication was sent has 40000 ton/year incinerator performance. The waste accepted within the framework of IZAYDAS waste acceptance and management criteria;

\section{1- Is weighed sensitively}

2- Has samples taken and analyzed with transportation from the relevant intermediate storage units

3- First spends $95-120 \mathrm{~min}$ in the rotating oven at $921-1150{ }^{\circ} \mathrm{C}$

4- Then spends minimum 2.5 seconds in the final incinerator at $923-1250{ }^{\circ} \mathrm{C}$

The steam obtained is used to produce electrical energy. For cooling of the waste gas produced by the final incinerator at
1050- $1250{ }^{\circ} \mathrm{C}$, it enters a waste temperature boiler with $2500 \mathrm{~m}^{2}$ area and exits after cooling to $180-200{ }^{\circ} \mathrm{C}$. Steam at $350{ }^{\circ} \mathrm{C} / 40$ bar pressure is produced at maximum 27.1 ton $/ \mathrm{hr}$, with the steam sent to steam turbine generator units and maximum 5.2 MW/hr output obtained (IZAYDAS, 2019).

Some of the energy produced meets the requirements of the facility, with the remaining energy sold.

As a result, waste medication that cannot be reused and forms an important hazardous waste that poisons organisms and humans by distributing micropollutants into the ecosystem is used in this way to provide two important gains. The first is that entry to the ecosystem is prevented and the second is that we transform toxic waste into electrical energy. 

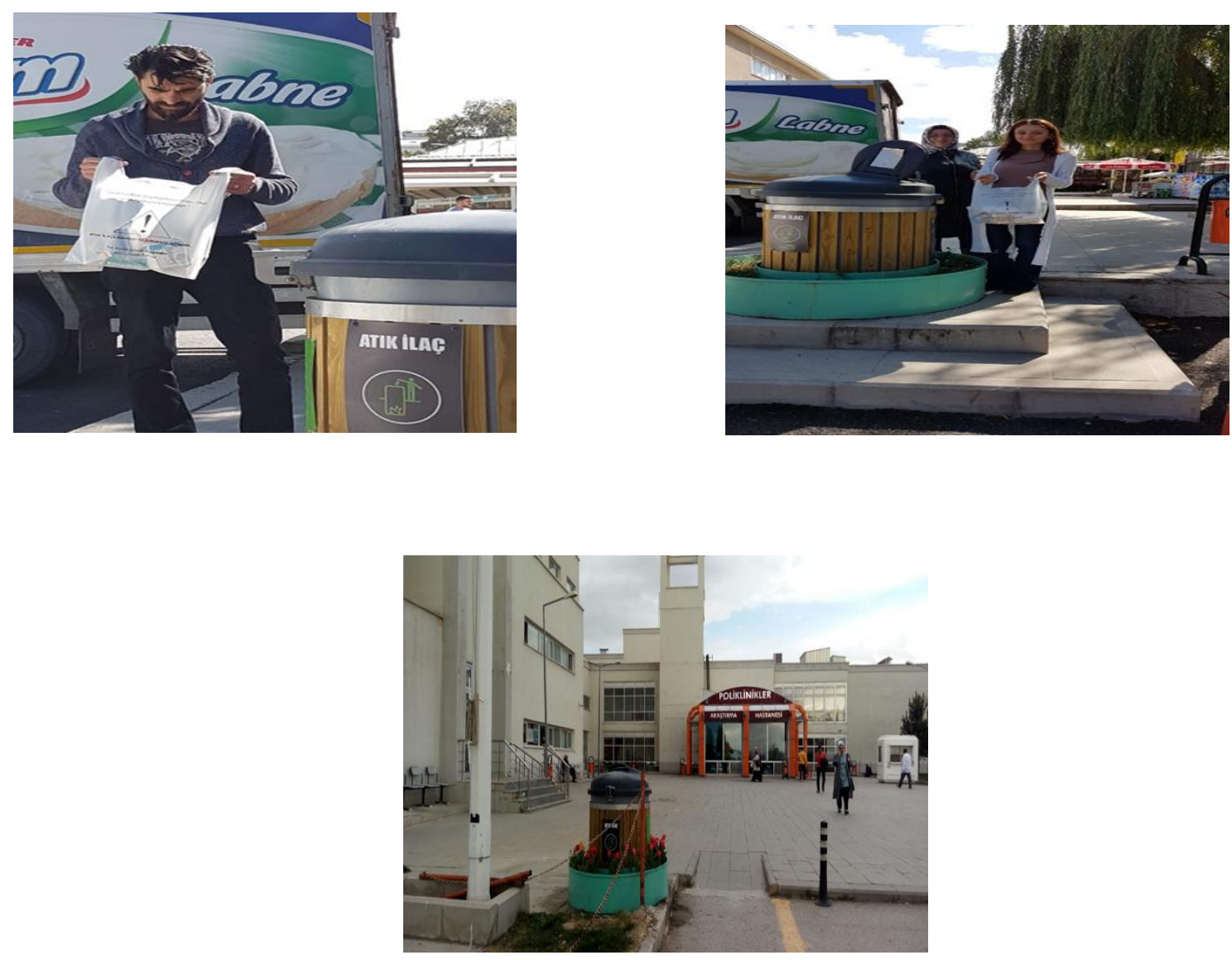

Figure 13. Use of the waste medication containers.

\section{Results and Discussion}

\subsection{Waste Medication Amounts Collected In The First Year}

Within the scope of the project, the amounts of waste medication collected from 1 June 2018 to 31 May 2019 can be seen in Table 2.

In the first 3-month period (1 June 2018 - 31 August 2018), $190.75 \mathrm{~kg}$ waste medication was collected, while in the second 3-month period (1 September 2018 - 30 November
2018) $261.40 \mathrm{~kg}$ waste medication was collected, in the third 3-month period (1 December 2018 - 28 February 2019) $310.70 \mathrm{~kg}$ waste medication and in the fourth 3-month period (1 March 2019-31 May 2019) $260.80 \mathrm{~kg}$ waste medication was collected. In total on an annual basis $1023.65 \mathrm{~kg} /$ year waste medication was collected and sent to the disposal (incinerator) facility as seen in Table 2. From 1 June 2019, the second annual process began with data being collected for further seasonal statistical studies. 
Table 2. Waste Medication Amounts (kg and \%) Collected in Containers at Five Different Points During the First Year

\begin{tabular}{|c|c|c|c|c|c|}
\hline $\begin{array}{c}\text { Container } \\
\text { Location }\end{array}$ & $\begin{array}{c}\text { First } \\
\text { Period } \\
\text { (Summer) } \\
\text { (June } \\
\text { July } \\
\text { August) } \\
\text { Kg }\end{array}$ & $\begin{array}{c}\text { Second } \\
\text { Period } \\
\text { (Autumn) } \\
\text { (September } \\
\text { October } \\
\text { November) } \\
\text { Kg }\end{array}$ & $\begin{array}{c}\text { Third } \\
\text { Period } \\
\text { (Winter) } \\
\text { (December } \\
\text { January } \\
\text { February) } \\
\text { Kg }\end{array}$ & $\begin{array}{c}\text { Fourth } \\
\text { Period } \\
\text { (Spring) } \\
\text { (March } \\
\text { April } \\
\text { May) } \\
\text { Kg }\end{array}$ & $\begin{array}{c}\text { 1 Year Total } \\
\text { (1 June } \\
\text { 2018) } \\
\text { 1 June 2019) } \\
\text { Kg }\end{array}$ \\
\hline $\begin{array}{l}\text { KYK FEMALE } \\
\text { DORMS }\end{array}$ & $\begin{array}{l}30.52 \\
(16 \%)\end{array}$ & $\begin{array}{c}48.36 \\
(18.5 \%)\end{array}$ & $\begin{array}{c}54.43 \\
(17.52 \%)\end{array}$ & $\begin{array}{c}45.22 \\
(17.34 \%)\end{array}$ & $\begin{array}{c}178.53 \\
(17.44 \%)\end{array}$ \\
\hline $\begin{array}{l}\text { UNIVERSITY } \\
\text { ENTRANCE }\end{array}$ & $\begin{array}{l}41.96 \\
(22 \%)\end{array}$ & $\begin{array}{c}54.14 \\
(20.71 \%)\end{array}$ & $\begin{array}{c}61.95 \\
(19.94 \%)\end{array}$ & $\begin{array}{c}54.46 \\
(20.88 \%)\end{array}$ & $\begin{array}{l}212.51 \\
(20.76 \%)\end{array}$ \\
\hline RESIDENCES & $\begin{array}{l}45.78 \\
(24 \%)\end{array}$ & $\begin{array}{c}56.31 \\
(21.54 \%)\end{array}$ & $\begin{array}{c}66.15 \\
(21.29 \%)\end{array}$ & $\begin{array}{c}58.11 \\
(22.28 \%)\end{array}$ & $\begin{array}{c}226.35 \\
(22.11 \%)\end{array}$ \\
\hline DENTISTRY & $\begin{array}{l}36.24 \\
(19 \%)\end{array}$ & $\begin{array}{c}50.53 \\
(19.33 \%)\end{array}$ & $\begin{array}{c}62.79 \\
(20.21 \%)\end{array}$ & $\begin{array}{c}50.02 \\
(19.18 \%)\end{array}$ & $\begin{array}{c}199.58 \\
(19.50 \%)\end{array}$ \\
\hline $\begin{array}{l}\text { RESEARCH } \\
\text { HOSPITAL }\end{array}$ & $\begin{array}{l}36.24 \\
(19 \%)\end{array}$ & $\begin{array}{c}51.96 \\
(19.88 \%)\end{array}$ & $\begin{array}{c}65.31 \\
(21.02 \%)\end{array}$ & $\begin{array}{c}51.20 \\
(19.63 \%)\end{array}$ & $\begin{array}{c}204.71 \\
(20.19 \%)\end{array}$ \\
\hline TOTAL & 190.75 & 261.40 & 310.70 & 260.80 & 1023.65 \\
\hline
\end{tabular}




\subsection{Statistical Evaluation of Data}

Data were investigated with the SPSS statistical program (IBM, 2019a; IBM, 2019b).

Table 3 shows the descriptive statistical results for waste medication collection data for the first, second, third and fourth periods.
In the first 3-month period, the maximum and minimum waste medication fill rates for containers were $57.23 \%$ for the Residences and $38.15 \%$ for the KYK Female Dorms in terms of mass percentage. Additionally, while the total container volume when full is maximum 800 liters, our data found the total fill volume at the maximum point reached 381.52 liters.

Table 3. Descriptive Statistics of Waste Medications Collected During Four Seasons

\begin{tabular}{|c|c|c|c|c|}
\hline $\begin{array}{c}\text { Statistical Analysis Of } \\
\text { Data }\end{array}$ & $\begin{array}{c}\text { First } \\
\text { Period } \\
\text { (Summer) } \\
\text { (June } \\
\text { July } \\
\text { August) }\end{array}$ & $\begin{array}{c}\text { Second } \\
\text { Period } \\
\text { (Autumn) } \\
\text { (September } \\
\text { October } \\
\text { November) }\end{array}$ & $\begin{array}{c}\text { Third } \\
\text { Period } \\
\text { (Winter) } \\
\text { (December } \\
\text { January } \\
\text { February) }\end{array}$ & $\begin{array}{c}\text { Fourth } \\
\text { Period } \\
\text { (Spring) } \\
\text { (March } \\
\text { April } \\
\text { May) }\end{array}$ \\
\hline $\begin{array}{l}\text { Maximum filled waste } \\
\text { medication } \\
\text { container }(\mathrm{kg})\end{array}$ & $\begin{array}{c}45.78 \\
\text { (Residences) }\end{array}$ & $\begin{array}{c}56.31 \\
\text { (Residences) }\end{array}$ & $\begin{array}{c}66.15 \\
\text { (Residences) }\end{array}$ & $\begin{array}{c}58.11 \\
\text { (Residences) }\end{array}$ \\
\hline $\begin{array}{l}\text { Minimum filled waste } \\
\text { medication } \\
\text { container }(\mathrm{kg})\end{array}$ & $\begin{array}{c}30.52 \\
\text { (KYK } \\
\text { Female } \\
\text { dorms) }\end{array}$ & $\begin{array}{c}48.36 \\
\text { (KYK } \\
\text { Female } \\
\text { dorms) }\end{array}$ & $\begin{array}{c}54.43 \\
(\mathrm{KYK} \\
\text { Female } \\
\text { dorms) }\end{array}$ & $\begin{array}{c}45.22 \\
(\mathrm{KYK} \\
\text { Female } \\
\text { dorms) }\end{array}$ \\
\hline $\begin{array}{l}\text { Mean amount filled }(\mathrm{kg} / 5 \\
\text { containers) }\end{array}$ & 38.15 & 52.28 & 62.14 & 52.16 \\
\hline $\begin{array}{l}\text { Mean as proportion of total } \\
\text { fill }(\%)\end{array}$ & 47.69 & 65.35 & 77.68 & 65.20 \\
\hline $\begin{array}{l}\text { Standard deviation for } 5 \\
\text { containers }(\mathrm{kg})\end{array}$ & 5.87 & 3.09 & 4.63 & 4.84 \\
\hline
\end{tabular}




\begin{tabular}{|l|c|c|c|c|}
\hline Total container volume (kg) & 80 & 80 & 80 & 80 \\
\hline $\begin{array}{l}\text { Proportion of maximum fill } \\
\text { to total fill (\% weight) }\end{array}$ & 57.23 & 70.39 & 82.69 & 72.64 \\
\hline $\begin{array}{l}\text { Proportion of minimum fill } \\
\text { to total fill (\% weight) }\end{array}$ & 38.15 & 60.45 & 68.04 & 56.53 \\
\hline $\begin{array}{l}\text { Total container volume } \\
\text { (Liter) }\end{array}$ & 800 & 800 & 800 & 800 \\
\hline $\begin{array}{l}\text { Container total fill volume } \\
\text { (Liter) }\end{array}$ & 381.52 & 522.80 & 621.44 & 521.6 \\
\hline $\begin{array}{l}\text { Proportion of total fill to total } \\
\text { volume (\%) }\end{array}$ & 47.69 & 65.35 & 77.68 & 65.20 \\
\hline
\end{tabular}

In the second 3-month period, the maximum and minimum waste medication fill rates for containers were $70.39 \%$ for the Residences and $60.45 \%$ for the KYK Female Dorms in terms of mass percentage. Additionally, while the total container volume when full is maximum 800 liters, our data found the total fill volume at the maximum point was calculated to be 522.80 liters.

In the third 3-month period, the maximum and minimum waste medication fill rates for containers were $82.69 \%$ for the Residences and $68.04 \%$ for the KYK Female Dorms in terms of mass percentage. Additionally, while the total container volume when full is maximum 800 liters, our data found the total fill volume at the maximum point reached 621.44 liters.

In the fourth 3-month period, the maximum and minimum waste medication fill rates for containers were $72.64 \%$ for the Residences and $56.53 \%$ for the KYK Female Dorms in terms of mass percentage. Additionally, while the total container volume when full is maximum 800 liters, our data found the total fill volume at the maximum point reached 521.6 liters. 


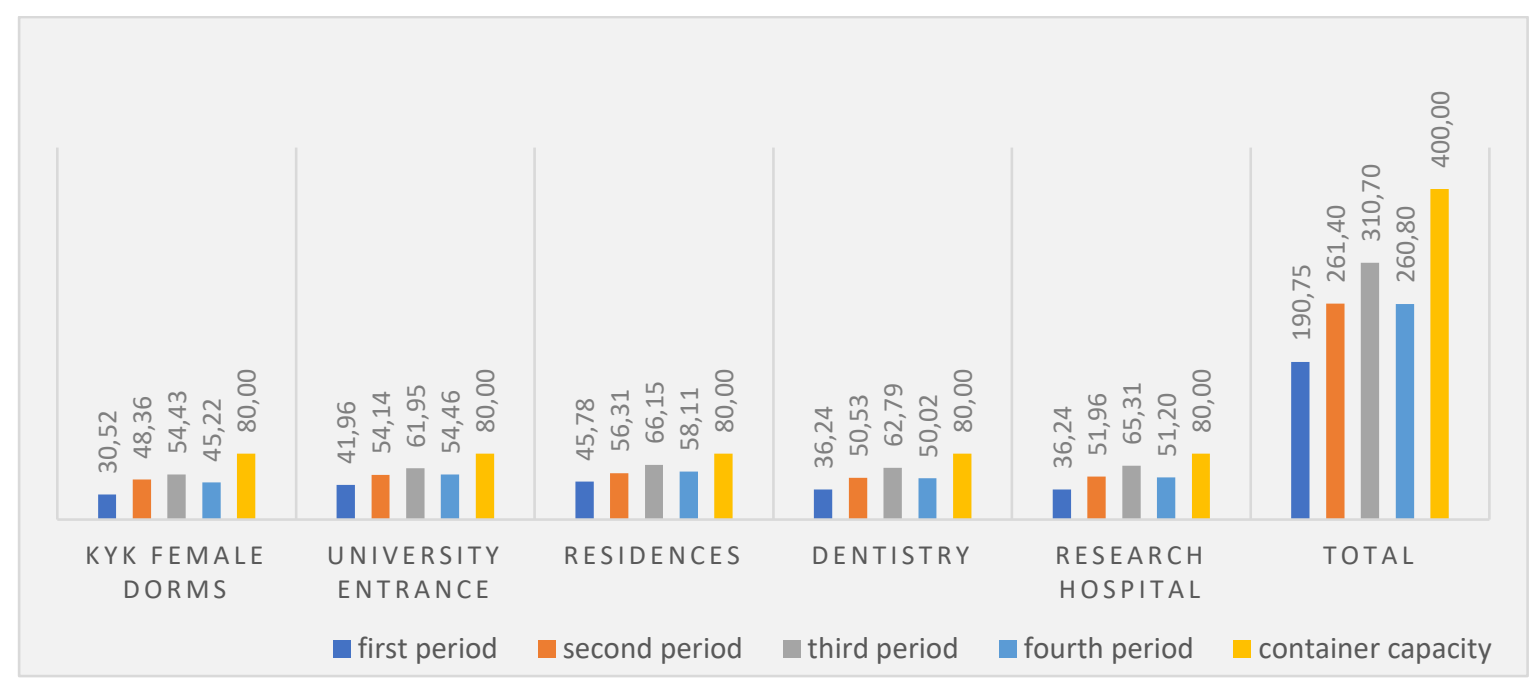

Figure 14. Comparison of first/second/third /fourth 3-month container capacity fill amounts $(\mathrm{kg})$

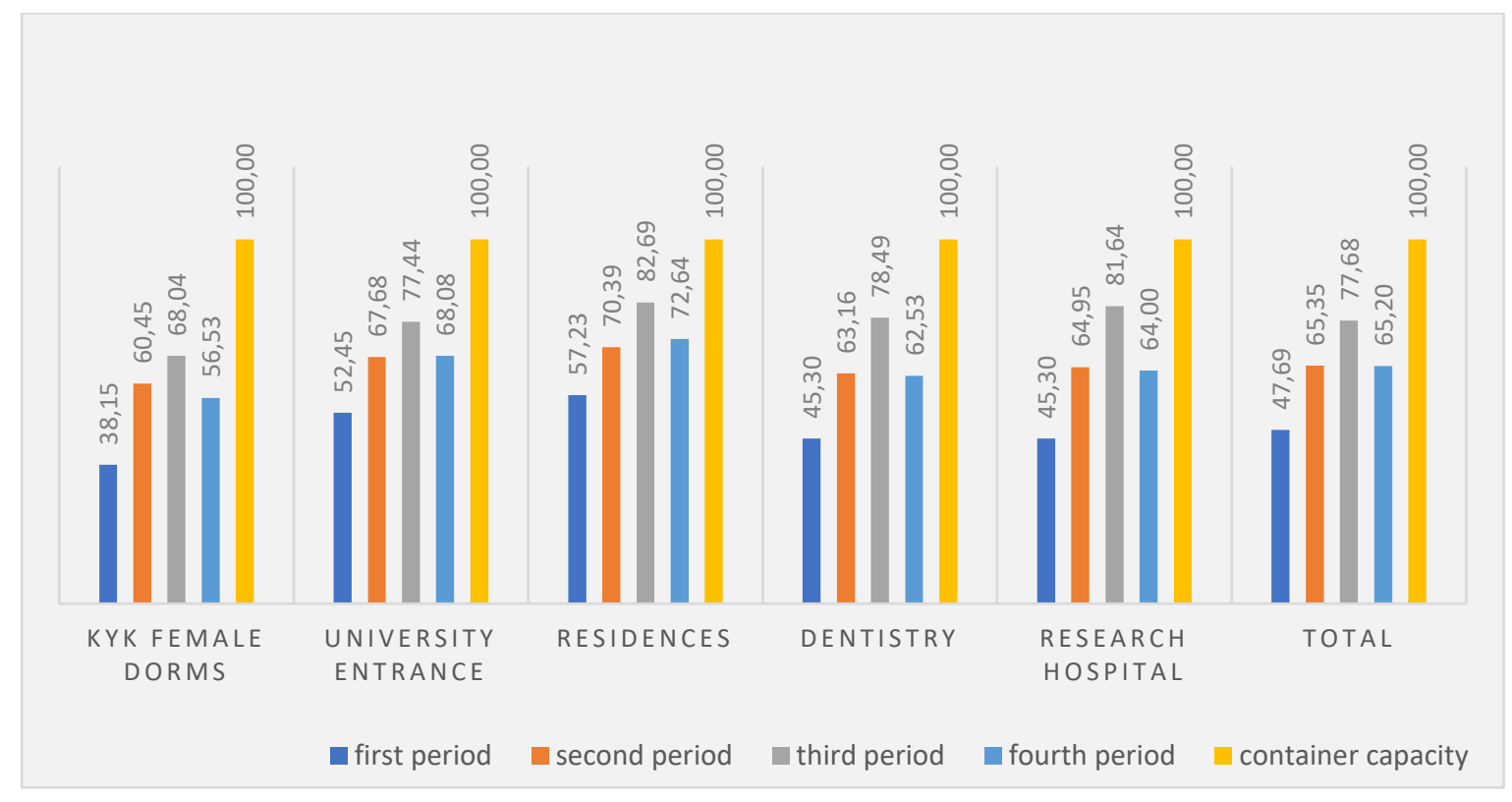

Figure 15. Comparison of first/second/third / fourth 3-month container capacity fill rate (\%) 


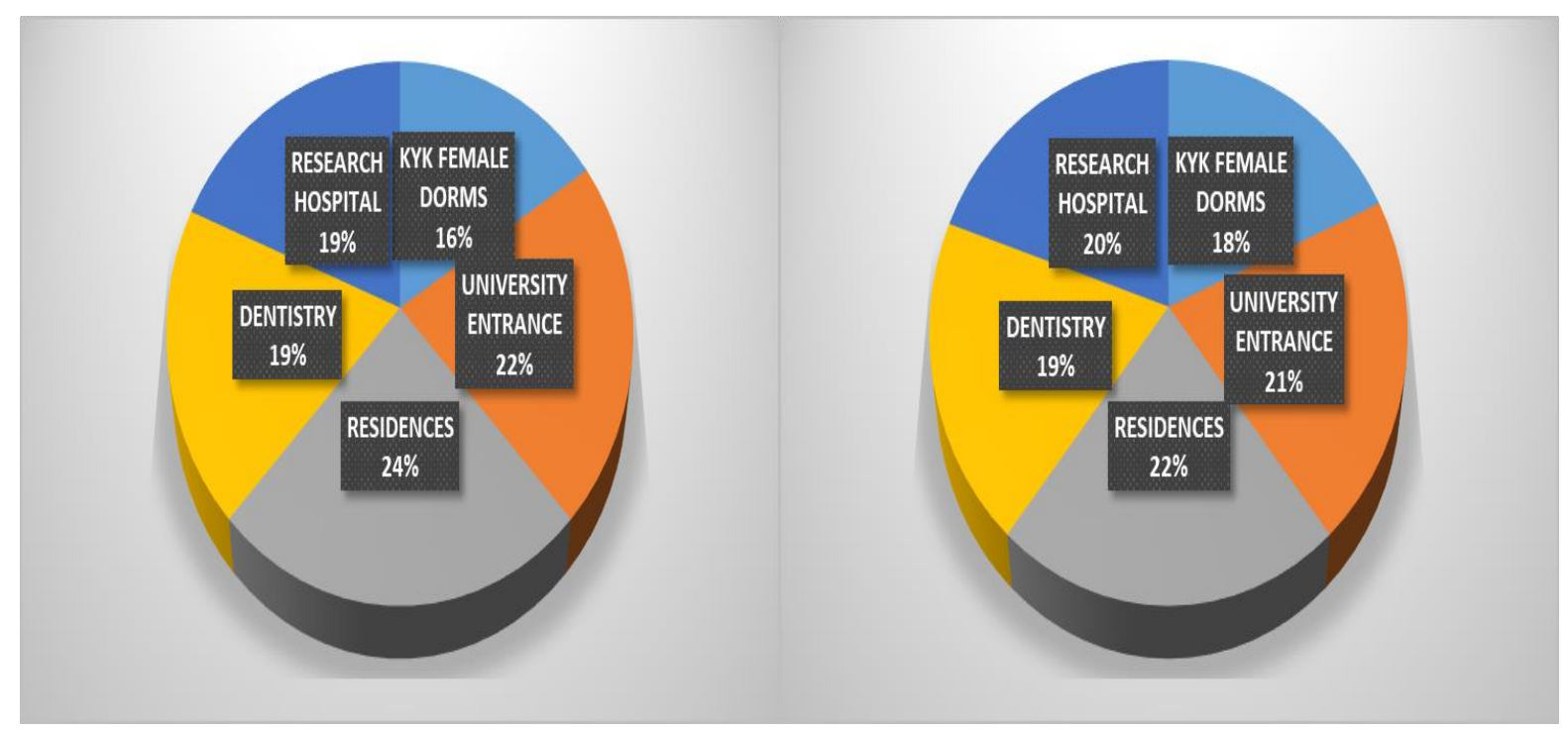

Figure. 16. a. Point/total rate for first 3-month period (\%) b. Point/total rate for second

3-month period (\%)

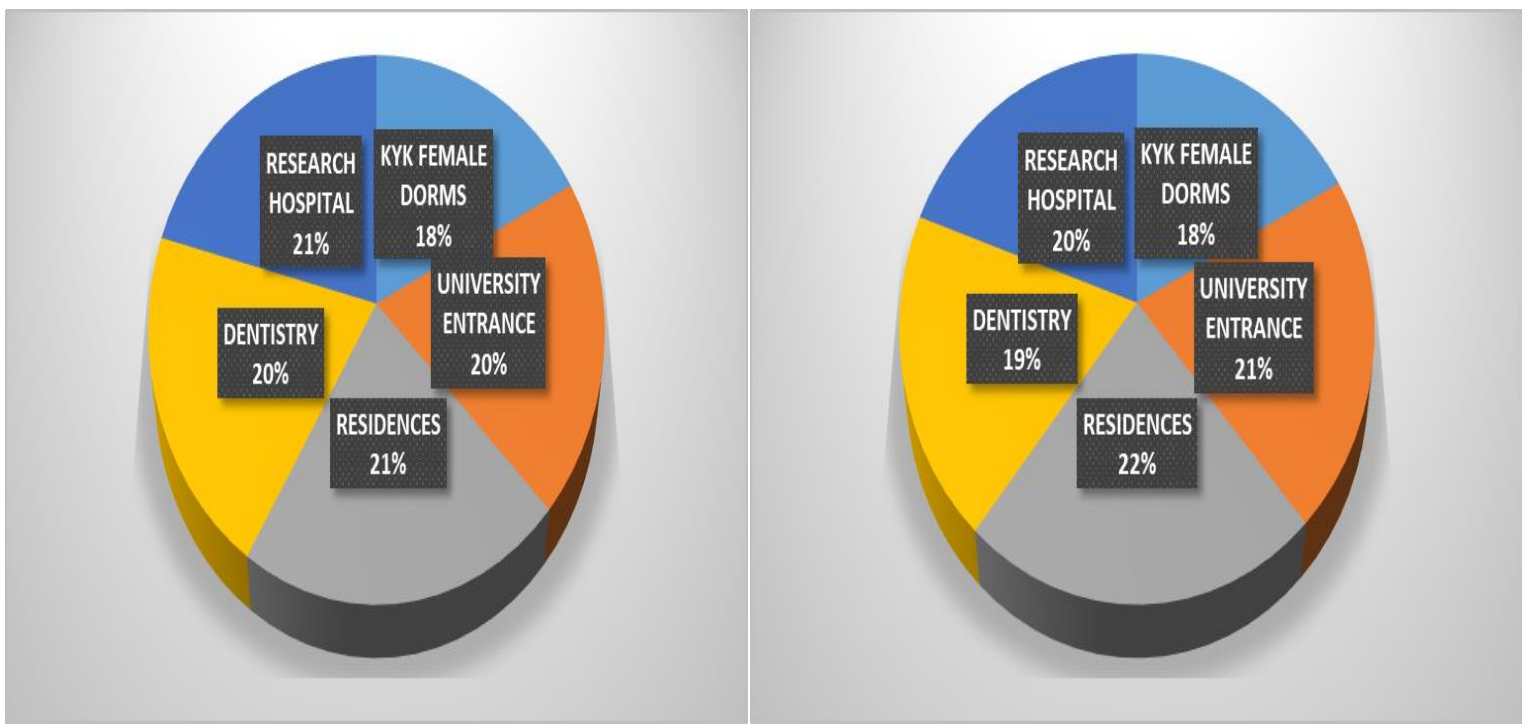

c. Point/total rate for third 3 -month period $(\%)$

Figure 16.a shows a pie graph comparing the total waste medication amount collected from each point in the first 3-month period as a proportion of total waste medication collected. The highest proportion was $24 \%$ from the Residence point, with the lowest proportion $16 \%$ at the KYK Female Dorms point

Figure 16.b shows the pie graph for the amount of waste medication collected at d. Point/total rate for fourth 3-month period (\%)

each point as a proportion of the total amount collected in the second 3-month period. The highest proportion was $22 \%$ from the Residence point, with lowest proportion of $18 \%$ from the KYK Female Dorms point.

Figure 16.c shows the pie graph for the amount of waste medication collected at each point as a proportion of the total amount collected in the second 3-month 
period. The highest proportion was $21 \%$ from the Residence point, with lowest proportion of $18 \%$ from the KYK Female Dorms point.

Figure 16.d shows the pie graph for the amount of waste medication collected at each point as a proportion of the total amount collected in the fourth 3-month period. The highest proportion was $22 \%$ from the Residence point, with lowest proportion of $18 \%$ from the KYK Female Dorms point.
With the aim of identifying whether the collected waste medication amounts in the five different containers abided by normal distribution or not, the KolmogorovSmirnov test found $\mathrm{p}$ value $\left(\mathrm{p}=0.200^{*}\right)$ indicating the data abided by normal distribution. According to the Levene homogeneity test, the $\mathrm{p}$ value was larger than $0.05(p=0.612)$ so the variance was determined to be homogeneous. Thus, both normal distribution and variance homogeneity indicated the one-way ANOVA test could be performed

Table 4. One-way ANOVA results for identification of differences between the seasons

\begin{tabular}{|l|l|c|c|}
\hline Seasons & $\begin{array}{c}\text { Mean waste } \\
\text { medication } \\
\text { amounts }\end{array}$ & F & P \\
\cline { 1 - 2 } SUMMER & $38.14 \pm 5.87^{\mathrm{c}}$ & \multirow{2}{*}{21.799} & \multirow{2}{*}{0.000} \\
\hline SPRING & $51.80 \pm 4.84^{\mathrm{b}}$ & & \\
\hline AUTUMN & $52.26 \pm 3.09^{\mathrm{b}}$ & & \\
\hline WINTER & $62.13 \pm 4.64^{\mathrm{a}}$ & & \\
& & & \\
\hline
\end{tabular}

The results of one-way ANOVA identified very significant differences between the seasons $(p<0.05)$. While there was no difference between spring and autumn seasons (b), summer (c) and winter (a) seasons were significantly different compared to each other and the spring and autumn seasons.

According to the one-way ANOVA test results, the seasonal means for waste medication collected at the five different points were $62.13 \mathrm{~kg}$ in the winter season, $52.26 \mathrm{~kg}$ in the autumn season, $51.80 \mathrm{~kg}$ in the spring season and $38.15 \mathrm{~kg}$ in the summer season.

\section{Conclusion and Recommendations}

With each passing day, we encounter new pollutants and effects in the micropollutant class. As a result, with the necessity to control these micropollutants in wastewater 
(urban, industrial) and drinking water treatment facilities (under current conditions, removal of MP in treatment facilities operating with conventional methods is difficult, even impossible), development of the most appropriate and sensitive methods for analysis of these micropollutants has become unavoidable. However, the most effective and applicable method under the zero-waste policy requires us to always consider the reality of controlling these pollutants at the source. Based on the principle of controlling the source, within the scope of our research, five $800 \mathrm{~L}$ specially-designed containers were placed at clearly noted points for collection of waste medication beginning in June 2018 in a pilot study in Atatürk University campus. As stated above, the containers were emptied 4 times within the year at 3-month intervals, the contents were carefully packed and sent to the Izaydaş incinerator facility for pyrolysis via an intermediate waste storage firm. The second annual process began in June 2019.

In the first annual process, a total of 190.75 $\mathrm{kg}$ was collected in the $1^{\text {st }}$ period (3 months/summer), $261.40 \mathrm{~kg}$ was collected in the $2^{\text {nd }}$ period ( 3 months/autumn), 310.70 $\mathrm{kg}$ was collected in the $3^{\text {rd }}$ period (3 months/winter) and $260.80 \mathrm{~kg}$ was collected in the $4^{\text {th }}$ period ( 3 months/spring) for a cumulative total of $1023.65 \mathrm{~kg}$ of waste medication collected and sent for incineration.

According to data obtained from Izaydaş hazardous waste incineration facility, the incineration capacity of the facility is 5400 $\mathrm{kg}$ hazardous waste/h. When this amount of hazardous waste is incinerated thermal value is $85 \mathrm{Gj} / \mathrm{h}$ and electric production capacity is $5.2 \mathrm{MW} / \mathrm{h}$ (IZAYDAS, 2019).
Based on this data, according to the results of our model study in Atatürk University campus, calculations based on $1023.65 \mathrm{~kg}$ waste medication/yr provided electrical production of nearly $1 \mathrm{MW} / \mathrm{h}$ or $1000 \mathrm{~kW} / \mathrm{h}$.

When this model study is performed on a city basis, the amount of waste medication that will be collected will increase to serious dimensions. If a small capacity incineration facility is built in our city, similar to IZAYDAS, this facility will provide the energy requirements of the city from just the collected waste medications. In fact, apart from waste medication, many varieties of hazardous waste are present and as is known, currently the most commonly chosen disposal method for waste entering the hazardous class is incineration. In addition to waste medication collected on a city basis, if neighboring cities are considered, it will be smart to provide serious investment for the future.

Additionally, our pilot study began in the university campus and is a sustainable and applicable study that can be expanded to all cities or even the whole country when statistical data is complete. Collection of a ton of waste medication within a year prevented mixing with the ecosystem by avoiding disposal in rubbish or sewer systems. Waste medications, micropollutants themselves or their metabolite products formed in the ecosystem, enter a continuous cycle in the ecosystem affecting water, organisms in aquatic environments and soil and from there passing to our food and easily reaching humans through biomagnification routes to cause all types of acute and chronic toxic effects including EDC effects and form an important class of hazardous waste. As a result of this study, we showed 
that this waste medication can be controlled in sustainable and easily applicable manner.

An important element in the study being sustainable and reaching the desired continuous efficiency is the sensitivity shown about the topic by our people and our stakeholders. Based on sustainability among people and the principle that a tree bends when young, it is important to continue social awareness studies uninterrupted with our students from preschool to university.

For this reason, an important part of the project was the social awareness aspect. In the name of social awareness, seminars and conferences (Figure 18a-b) were, and continue to be, organized at certain periods in schools from preschool to high school level. Additionally, in coordination with Atatürk University Faculty of Communication, a public information spot was prepared to reach all sections from seven to seventy years about the topic on TV channels; the first related to awareness and information about waste medication in



Figure 17. (a) Waste medication collection container at sample point
Turkey. Local press releases were made at certain periods (Figure 19). Informative posters were displayed on city billboards (Figure 20a), with brochures prepared (Figure 21) and specially-designed recyclable waste medication carrying bags (Figure 17b) left during short information visits to as many houses and businesses as possible. Specially-prepared posters were continuously displayed on noticeboards in schools and faculties (Figure 20b). Studies about messages sent to mobile telephones continue. Additionally, during our research to date no application has placed speciallydesigned containers (smart container design studies continue) buried underground at public points in accordance with certain criteria to accumulate waste medication and continuously check all details until the destruction stage.

As seen in Figure 17a, landscaping studies were completed so our waste medication containers attracted more attention and had a sympathetic visual appearance when in use.

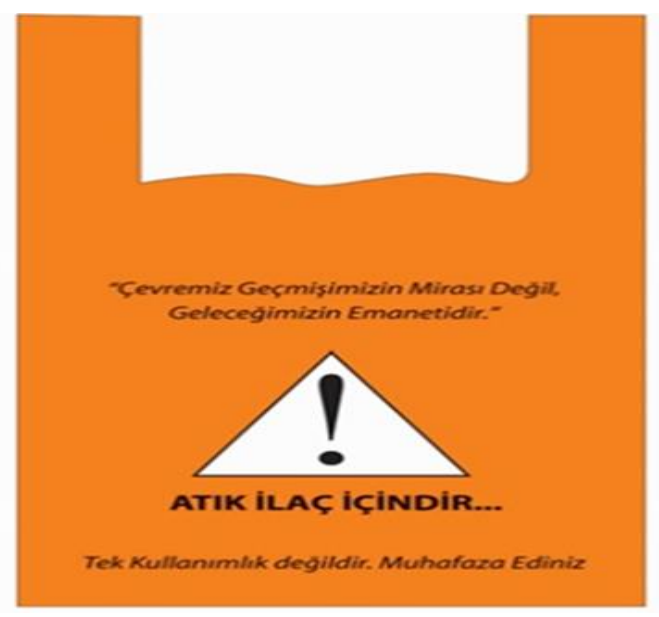

(b) Specially-designed recyclable waste medication bag 


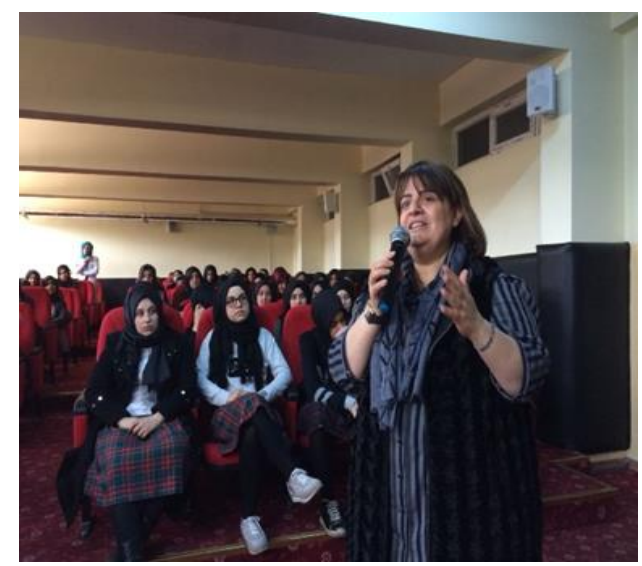

Figure 18. (a) Seminars and conferences for primary and middle

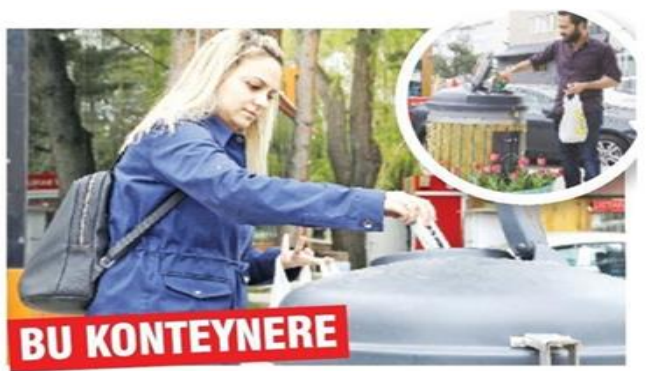

\section{Çöp değil atık ilaç bırakılıyor}

ERZURUM Atatürk Oniversitesi Mü- $\quad$ yllik araștrma ve incelemeler sonucu hendislik Fakuiltesi Cevre Mühendisigigi Atk llaç Konteyneri Projesi'ni hayata Bölümū öğrencileri, önemli çevre so- geciren ögrenciler, üniversite kampúrunlanndan biri olan, attk haline get. süne kurduklan attk ilaç konteynerlemiș ilaçlann çevre ve insan sağlığina niyle, zararlı maddelerin çevreye ve inzarar vermeden kontrol altina alinma- sana etki etmeden kontrol altina alinsı için çalışma bașlattı. Yaklașik bir masını sağladı. (AA)

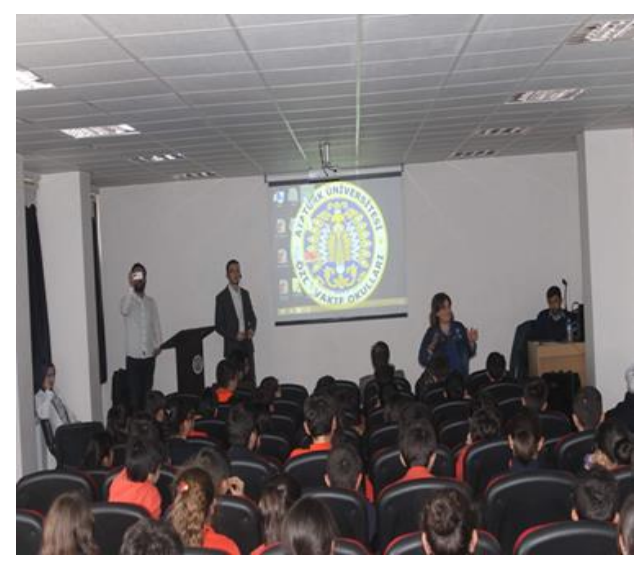

(b) Informing our young siblings

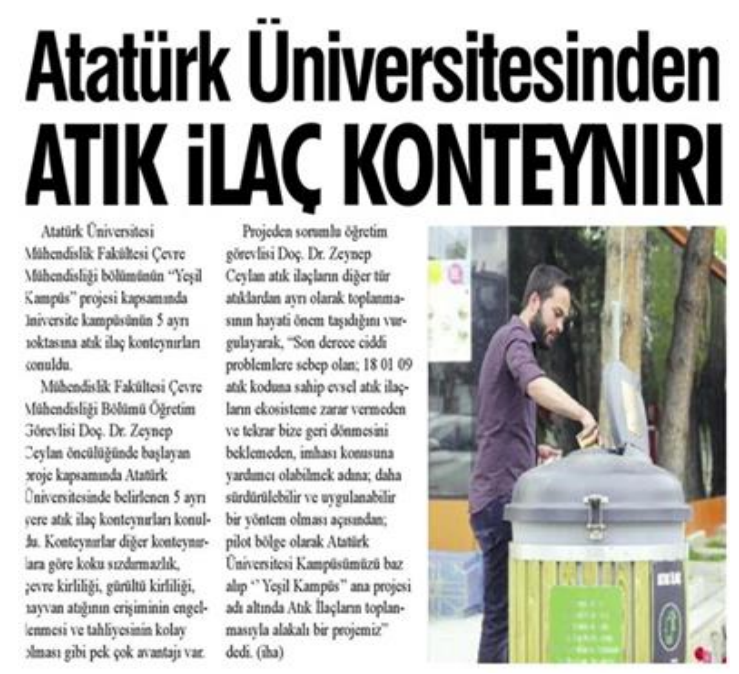

Figure 19. News related to waste medication containers in the press

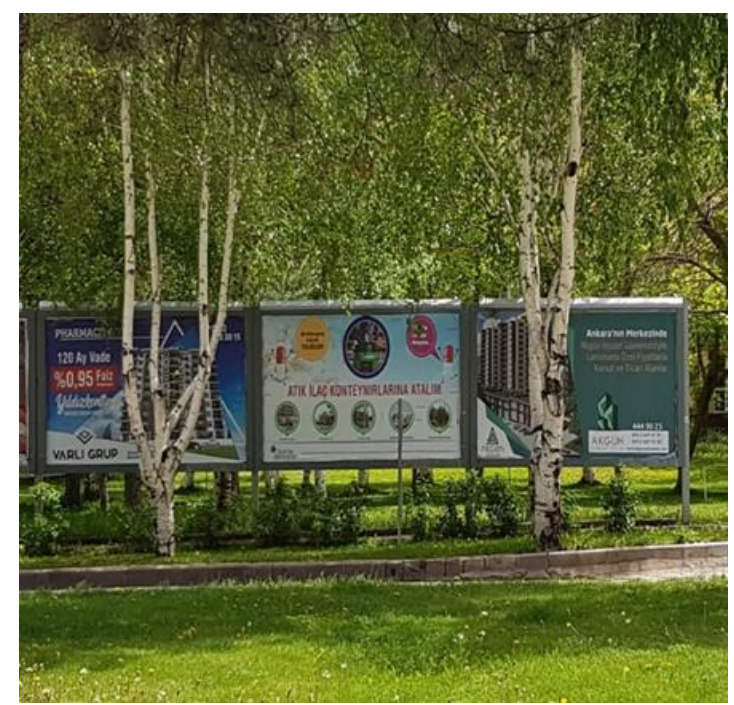

Figure 20. (a) Information posters on city billboards,

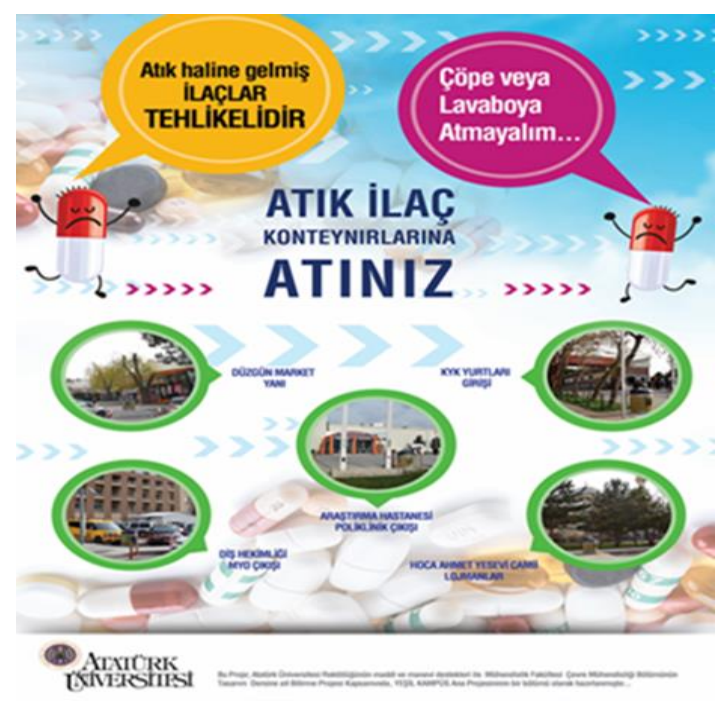

(b) Specially-prepared posters on school and faculty noticeboards. 

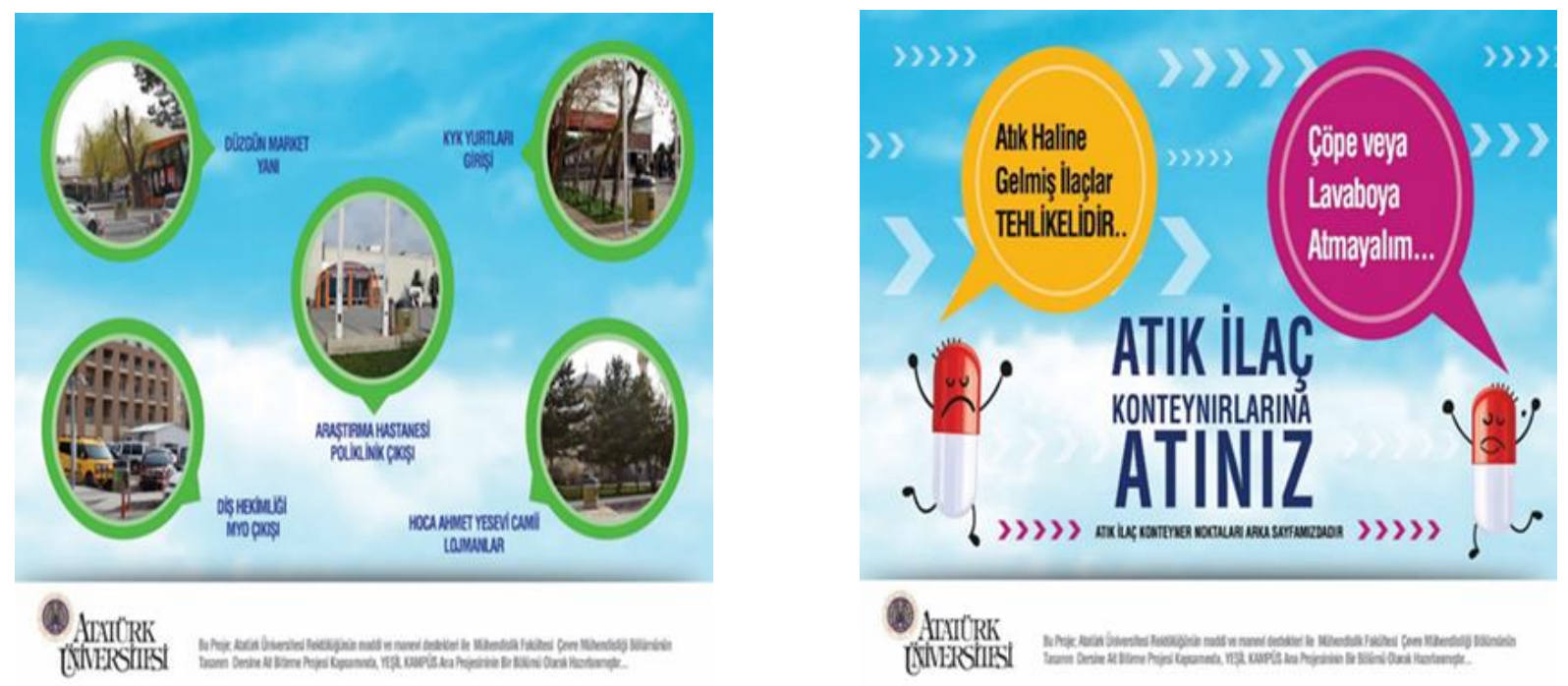

Figure 21. Front-back appearance of brochures

From the first stage of the study, within the scope of final projects for students attending Atatürk University Faculty of Engineering Department of Environmental Engineering, final theses were prepared with active work during the 4 periods. Our project matured with our 3rd thesis, which was awarded 1st place in the East Anatolia region and 3rd place in Turkey in general during the 2238 Entrepreneurship and Innovation Competition in 2018 in the Interuniversity Project competition organized by the Scientific and Technological Research Council of Turkey (TÜBİTAK).

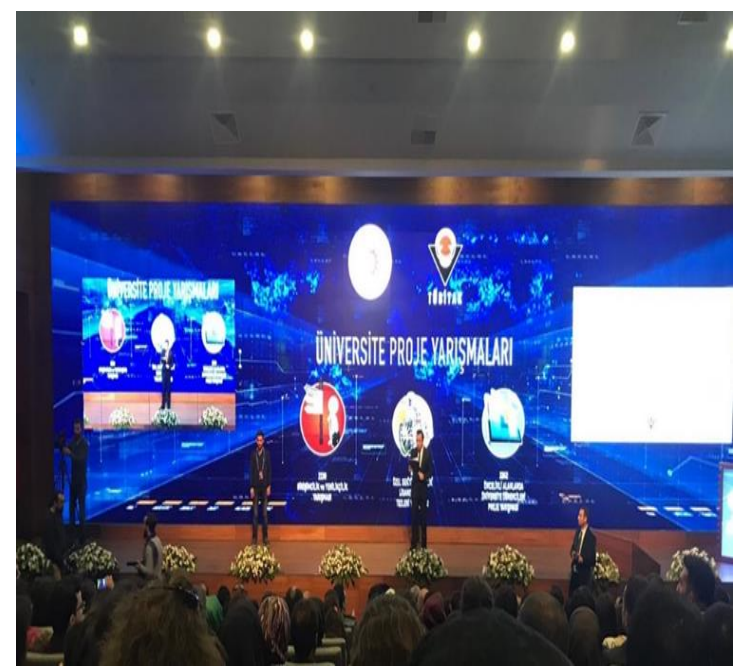

Figure 22. Turkish inter-university project competition, 2018 (Ankara)
The sustainable and applicable aspects of our project have attracted attention and in cooperation with Erzurum 13th region Association of Pharmacists-Provincial Health Directorate, the metropolitan municipality has begun feasibility studies to apply this project throughout the city center in a short period.

\section{Acknowledgment}

Firstly, we would like to thank Atatürk University Rector, Prof. Dr. Ömer ÇOMAKLI, for his unceasing material and spiritual support in completing our study. We owe a debt of gratitude to the General Secretary of the Rectorate and all other units, and to all campus residents for sincere and continuing support of our project.

\section{References}

Arp, H.P., 2012. "Emerging decontaminants", Environ. Sci. Technol., 46, 4259-4260.

Barbosa, M.O., Moreira, N.F.F., Ribeiro, A.R., Pereira, M.F.R. and Silva, A.M.T., 2016. "Occurrence and removal of organicmicropollutants: an overview of the 
watch list of EU Decision 2015/495”, Water Res., 94, 257-279.

Burke, V., Greskowiak, J., Asmuß, T., Bremermann, R., Taute, T. and Massmann, G., 2014. "Temperature dependent redox zonation and attenuation of wastewaterderived organic micropollutants in the hyporheic zone", Sci. Total Environ., 53, 482-483.

Ceylan, Z., Mustafaoğlu, D., (2018). "Mikrokirleticilerin izleme analiz ve aritım yöntemleri 1st edition", Güven Plus Grup Danışmanlık AŞ. Yayınları, 308-329 ISBN 978-605-7594-06-8.

Cordy, G.E., Duran, N.L., Bouwer, H., Rice, R.C., Furlong, E.T., Zaugg, S.D., Meyer, M.T., Barber, L.B. and Koplin, D.W., 2004. "Do pharmaceuticals, pathogens, and other organic waste water compounds persist when waste water is used for recharge?", Ground Water Monit. $R ., 24,58-69$.

Das, S., Ray, M.R., Wan, J., Khan, A., Chakraborty, T., Ray, M.B., (2017). "Micropollutants in Wastewater: Fate and Removal Processes", Physico-Chemical Wastewater Treatment and Resource Recovery, 75-117. DOI: 10.5772/65644.

Deblonde, T., Cossu-Leguille, C. and Hatemann, P., 2011. "Emerging pollutants in wastewater: A review of the literatüre", International Journal of Hygiene and Environmental Health, 214, 442-448.

Emmanuel, E., Keck, G., Blanchard, J., Vermande, P. and Perrodin, Y., 2004. "Toxicological effects of disinfections using sodium hypochlorite on aquatic organisms and its contribution to AOX formation in hospital wastewater", Environment International, 30, 891-900.
Gulde, R., Meier, U., Schymanski, E.L., Kohler, H.P.E., Helbling, D.E., Derrer, S., Rentsch, D. and Fenner, K., 2016. "Systematic exploration of biotransformation reactions of aminecontaining micropollutants in activated sludge", Environ. Sci. Technol., 50, 2908-2920.

Hernando, M.D., Mezcua, M., FernándezAlba, A.R. and Barceló D., 2006. "Environmental risk assessment of pharmaceutical residues in wastewater effluents, surface waters and sediments", Talanta, 69, 334-342.

Kolpin, D.W., Furlong, E.T., Meyer, M.T., Thurman, E.M., Zaugg, S.D., Barber, L.B. and Buxton, H.T., 2002. "Pharmaceuticals, hormones, and other organic wastewater contaminants in U.S. streams, 1999-2000: a national reconnaissance", Environ. Sci. Technol., 36, 1202-1211.

Le-minh, N., Khan, S.J., Drewes, J.E. and Stuetz, R.M., 2010. "Fate of antibiotics during municipal water recycling treatment processes", Water Res., 44, 4295-4323.

Loos, R., Carvalho, R., Antonio, D.C., Comero, S., Locoro, G., Tavazzi, S., Paracchini, B., Ghiani, M., Lettieri, T., Blaha, L., Jarosova, B., Voorspoels, S., Servaes, K., Haglund, P., Fick, J., Lindberg, R.H., Schwesig, D. and Gawlik, B.M., 2013. "EU-wide monitoring survey on emerging polar organic contaminants in wastewater treatment plant effluents", Water Res., 47, 6475-6487.

Luo, Y., Guo, W., Ngo, H.H., Nghiem, L.D., Hai, F.I., Zhang, J., Liang, S., 2014. "A review on the occurrence of micropollutants in the aquatic environment and their fate and removal during wastewater treatment", Science of the Total Environment, 473-474, 619-641. 
Markot, J., Rossi, L., Barry, D.A., Holliger, C., 2015. "A review of the fate of micropollutants in wastewater treatment plants", Wires Water, 2, 457-487.

Mill, T., (1980). "Data needed to predict the environmental fate of organic chemicals. In. R. Haque (ed.) Dynamics, exposure and Hazard Assesment of Toxic Chemicals", Ann Arbor Science, Michigan, 297.

Muter, O., Plerkons, I., Selga, T., Berzins, A., Gudra, D., Radovica-Spalvina, L., Fridmanis, D. and Bartkevics, V., 2017. "Removal of pharmaceuticals from municipal wastewaters at laboratory scale by treatment with activated sludge and biostimulation", Sci. Total Environ., 584585, 402-413.

Nas, B., Dolu, T., Ateş, H., Argun, M.E., Yel, E., 2017. "Treatment Alternatives for Micropollutant Removal in Wastewater", Selcuk University Journal of Engineering Science and Technology(SUJEST), 5(2), 133-143.

Padhye, L.P. and Tezel, U., 2013. "Fate of Environmental Pollutants", Water Environment Research, 85(10), 1734-1785.

Park, J., Yamashita, N., Wu, G. and Tanaka, H., 2017. "Removal of pharmaceuticals and personal care products by ammonia oxidizing bacteria acclimated in a membrane bioreactor: contributions of cometabolism and endogenous respiration", Sci. Total Environ., 605-606, 18-25.

Phillips, J.P., Schubert, C., Argue, D., Fisher, I., Furlong, E.T., Foreman, W., Gray, J. and Chalmers, A., 2015. "Concentrations of hormones, pharmaceuticals and other micropollutants in groundwater affected by septic systems in New England and New York", Sci. Total Environ., 512, 43-54.
Ribeiro, A.R., Pedrosa, M., Moreira, N.F.F., Pereira, M.F.R. and Silva, A.M.T., 2015. "Environmental friendly method for urban wastewater monitoring of micropollutants defined in the Directive 2013/39/EU and Decision 2015/495/EU', $J$. Chromatogr. A., 1418, 140-149.

Schwarzenbach, R.P., Escher, B.I., Fenner, K., Hofstetter, T.B., Johnson, C.A., Von Gunten, U. and Wehrli, B., 2006. "The challenge of micropollutants in aquatic systems", Science, 313, 1072-1077.

Segura, P.A., 2011. "Quantification of carbamazepine and atrazine and screening of Suspectorganic contaminants in surface and drinking waters", Chemosphere, 84, 1085-1094.

Sousa, J.C.G., Ribeiro, A.R., Barbosa, M.O., Pereira, M.F.R. and Silva, A.M.T., 2018. "A review on environmental monitoring of water organic pollutants identified by EU guidelines", J. Hazard. Mater., 344 (Supplement C), 146-162.

The BEK website, 2019. http://aits.bek.org.tr/ [Online]. Available: 20 January 2019

The CSB website 2019. http://cygm.csb.gov.tr/tehlikeli-atiklarinyonetimi-duyuru-89435

[Online].

Available: 20 January 2019

The IBM website, 2019a. https://www.ibm.com/tr-tr/products/spssstatistics/resources [Online]. Available: 20 January 2019.

The IBM website, 2019b. https://www.ibm.com/analytics/spssstatistics-software [Online]. Available: 20 January 2019.

The IEIS website, 2019. http://www.ieis.org.tr/ieis/tr/indicators/33/t 
urkiye-ilac-pazari [Online]. Available: 20 January 2019.

The IZAYDAS website, 2019. https://www.izaydas.com.tr/ [Online]. Available: 20 January 2019.

The Resmigazete website, 2019a. http://www.resmigazete.gov.tr/eskiler/2005 /03/20050314-1.htm [Online]. Available: 20 January 2019.

The Resmigazete website, $2019 \mathrm{~b}$. http://www.resmigazete.gov.tr/eskiler/2011 /04/20110426-9.htm [Online]. Available: 20 January 2019.

Tousova, Z., Oswald, P., J. Slobodnik, J., Blaha, L., Muz, M., Hu, M., Brack, W., Krauss, M., Di Paolo, C., Tarcai, Z., Seiler, T.B., Hollert, H., Koprivica, S., Ahel, M., Schollée, J.E., Hollender, J., Suter, M.J.F., Hidasi, A.O., Schirmer, K., Sonavane, M., Ait-Aissa, S., Creusot, N., Brion, F., Froment, J., Almeida, A.C., Thomas, K., Tollefsen, K.E., Tufi, S., Ouyang, X., Leonards, P., Lamoree, M., Torrens, V.O., Kolkman, A., Schriks, M., Spirhanzlova, P., Tindall, A. and Schulze, T., 2017. "European demonstration program on the effect-based and chemical identification and monitoring of organic pollutants in European surface waters", Sci. Total Environ., 601, 1849-1868.

World Health Organization, 2012. "Pharmaceuticals in drinking-water", France.

Verlicchi, P., Galletti, A., Petrovic, M. and Barcelo, D., 2010. "Hospital effluents as a source of emerging pollutants: an overview of micropollutants and sustainable treatment options", Journal of Hydrology, 389, 416-428.

Vieno, N.M., H€arkki, H., Tuhkanen, T. and Kronberg, L., 2007. "Occurrence of pharmaceuticals in river water and their elimination in a pilot-scale drinking water treatment plant", Environ. Sci. Technol., 41, 5077-5084.

Yang, M. and Zhang, X., 2016. "Current trends in the analysis and identification of emerging disinfection byproducts", Trends Environ. Anal. Chem., 10, 24-34.

Yaşar, A., Doğan, E.C. and Arslan, A., 2013. "Macro and Micro Pollutants and Treatment Options in Hospital Wastewaters", Erciyes University Journal of the Institute of Science and Technology, 29(2), 144-158. 